УДК 004.942

DOI: 10.17277/voprosy.2017.04.pp.231-236

\title{
EXPERIMENTAL SETUPS FOR STUDIES OF BLOOD FLOW IN ARTERIES OF CARDIOVASCULAR SYSTEM
}

\author{
S. V. Sindeev, S. V. Frolov, D. Liepsch \\ Tambov State Technical University, Tambov, Russia; \\ Munich University of Applied Sciences, Munich, Germany \\ Reviewed by Doctor of Technical Sciences, Professor T. I. Chernyshova
}

Keywords: biomechanics; hemodynamics; systemic circulation.

\begin{abstract}
Hemodynamics plays an important role in genesis of such vascular diseases as atherosclerosis, thrombosis and aneurysm. The better understanding of flow conditions in the regions which prone to have such diseases helps a physician in clinical decisionmaking process. In this study, we present a detailed description of two experimental setups for evaluation of blood flow in arteries of cardiovascular system. The experimental fluid could be a Newtonian or non-Newtonian. The same dimensionless parameters - the Reynolds and Strouhal numbers - should be used for a comparison of Newtonian and non-Newtonian fluid in models. Experimental setup for visualization of the flow could be used as a preliminary tool for the fast detection of main flow features. The detected regions could be studied in detail by the experimental setup with a high-precision measuring device. The measured flow field should be analyzed to detect the regions prone to vascular diseases and estimate the risk of a disease. The described experimental setups could be used to assist a physician during the clinical decision marking process.
\end{abstract}

Introduction. Hemodynamics plays an important role in genesis of such vascular diseases as atherosclerosis, thrombosis and aneurysm [1-3]. The better understanding of flow conditions in the regions which prone to have such diseases helps a physician in clinical decision making process [4]. Currently available clinical methods, such as ultrasound and MRI, have the restrictions in spatial and temporal resolution and could not be applied for hemodynamics studies in some cases. Numerical simulation of blood flow in arteries of

Синдеев Сергей Вячеславович - старший научный сотрудник управления фундаментальных и прикладных исследований; Фролов Сергей Владимирович - доктор технических наук, профессор, заведующий кафедрой «Биомедицинская техника», e-mail: sergej.frolov@, gmail.com, ТамбГТУ, г. Тамбов, Россия; Липш Дитер - PhD, профессор кафедры механики, Мюнхенский университет прикладных наук, г. Мюнхен, Германия. 


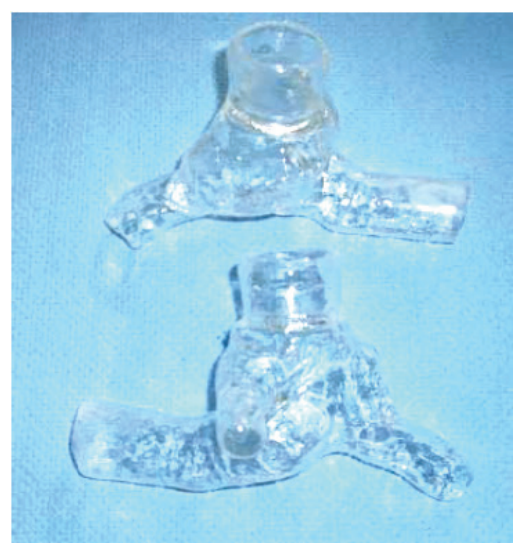

Fig. 1. Example of silicone model of artery cardiovascular system is considered as the most promising tool for study of hemodynamics in selected region of cardiovascular system [5-7]. However, due to the high computational complexity and time limitations, the results of numerical simulations are not verified with an experiment. Moreover, in a case of emergency, the flow-pattern in selected artery of cardiovascular system should be estimated in a clinically reasonable time. For such cases the experimental setups could be used to determine the main hemodynamic characteristics in selected artery [8].

The aim of the study is to present a detailed description of experimental setups which could be used in a clinical practice for evaluation of the main hemodynamic characteristics in selected artery of cardiovascular system.

\section{Methods}

Model preparation. MRI-data should be segmented to obtain the patientspecific geometry of selected artery. After the visual inspections the obtained model should be post-processed in order to eliminate the surface irregularities and defects. A wax model of artery could be prepared using 3D printing technique. After this, the model should be covered by the layers of silicone until the thickness of silicone wall will be sufficient. Then the wax should be poured out, to keep only the shell model. The example of silicone model is shown in Fig. 1.

Measuring methods. Two measuring methods could be used for the experimental evaluation of hemodynamic parameters: LDA (laser Doppler anemometry) and PIV (particle image velocimetry). The LDA method uses the Doppler shift of laser beam to measure the velocity of the fluid in the silicone model. The usage of this method requires keeping the same refraction index for silicone wall and for experimental fluid. The LDA device could measure a velocity at the point in one direction (1D LDA) or at three directions (3D LDA), but with a less spatial resolution. The PIV method is based on the estimation of the velocity for seeding points. A position of the seeding points at one time step is used as a reference to derive the velocity field at the next time moment. It is done by subtraction of the old coordinates of the seeding points from the new ones. The advantage of the PIV against the LDA is that the flow field could be obtained for the whole cross-section, whereas the LDA requires point-by-point measurements.

Experimental fluid. To simulate the flow characteristics of blood, a blood analog should be used which has a refraction index identical to that of the silicone wall. Blood is a non-Newtonian fluid (Fig. 2), however the experimental fluid could be a Newtonian or non-Newtonian. Selection of particular type of the fluid depends

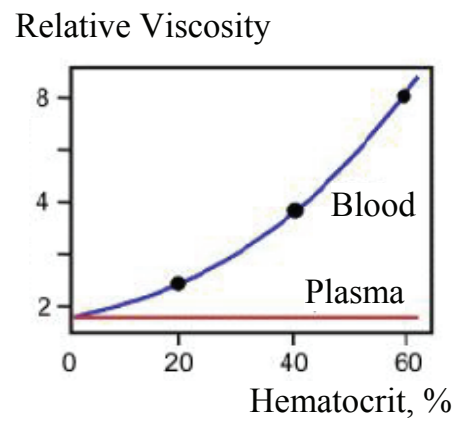

Fig. 2. Relative viscosity of blood over hematocrit 
on the aim of a study. A mixture of glycerol and water traditionally used to obtain an experimental fluid with Newtonian behavior. Preparation of nonNewtonian fluid requires is complicated and requires a lot of effort to match the curve for viscosity between experimental fluid and blood. An example of experimental fluid with non-Newtonian properties is fluid which consists of $51 \%$ by weight aqueous Dimethylsulfoxide into which various polyacrylamides are added (0.0035 \% Separan AP-302 and $0.0025 \%$ AP-45, Dow Chemical). The rheological behavior of this fluid is nearly identical to

ETA, $\mathrm{mPa} \cdot \mathrm{s}$

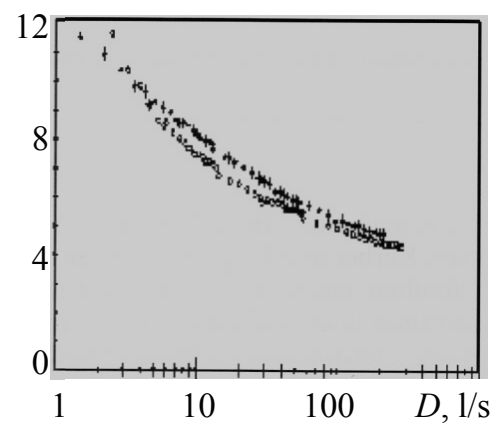

Fig. 3. Comparison of viscosity for blood and experimental fluid:

ETA - dynamic viscosity of fluid; $\mathrm{D}$ - shear rate that of blood with a hematocrit of $46 \%$.

Figure 3 compares the viscosity over the shear rate of the experimental fluid at $21{ }^{\circ} \mathrm{C}$ with the values for human blood, with hematocrits of 46 and $42 \%$ at $37^{\circ} \mathrm{C}$. The viscosity of the experimental fluid and the blood samples were measured at the respective temperatures with this rotational viscosimeter. The density of the mixture was equal to $1050 \mathrm{~kg} / \mathrm{m}^{3}$ of that of blood.

The same dimensionless parameters should be used for a comparison of Newtonian and non-Newtonian fluid in models. Thus the Reynolds and Strouhal numbers should be the same both for Newtonian and non-Newtonian fluids. A representative viscosity for non-Newtonian fluid should be used for calculation of the Reynolds number.

$$
\operatorname{Re}=\frac{\bar{u} d \rho}{\eta_{\text {rep }}}
$$

where $\bar{u}$-average velocity at the inlet; $d$-proximal diameter of artery; $\rho$ - fluid density; $\eta_{\text {rep }}$ - representative viscosity.

An average velocity could be calculated from the flow rate as

$$
\bar{u}=\frac{4 \dot{V}}{\pi d^{2}}
$$

where $\dot{V}-$ is flow rate.

In order for two flows to be similar they must have the same geometry and the same dimensionless parameters. The definition says that two flows may be considered similar, if a stable ratio is created between geometric and characteristic physical parameters of the flows be compared at arbitrary correlated points.

The representative shear rate for non-Newtonian fluid could be calculated from the known flow rate $\dot{V}$ at the inlet of an artery and the proximal radius $r$ as follows:

$$
\gamma_{\text {rep }}=\frac{\dot{V}}{r^{3}}
$$

Using this value the representative viscosity $\eta_{\text {rep }}$ could be obtained from the curve of shear stress-over-shear rate. If the measured data is not available, 


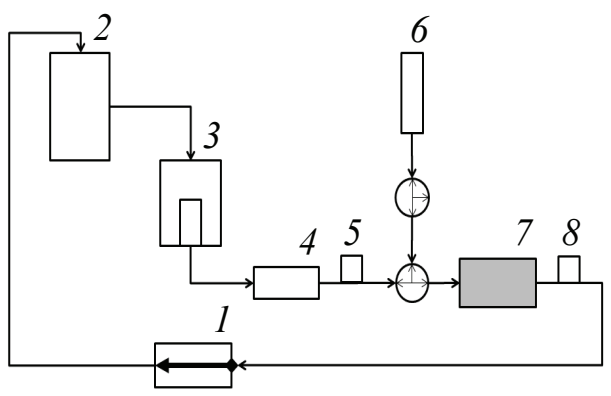

Fig. 4. Block diagram of experimental setup for visualization of flow in selected artery with particles

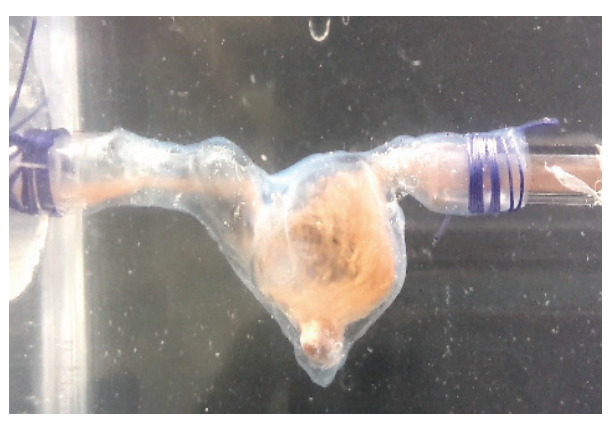

Fig. 5. Flow visualization in the artery using particles

the representative viscosity could be calculated from the coefficients of Power Law model as

$$
\eta_{\text {rep }}=\frac{k \pi}{4}\left(\frac{2 \pi \bar{u}}{d}\right)\left(\frac{3 n+1}{\pi n}\right)^{n},
$$

where $k$ and $n$-are coefficients of Power Law viscosity model.

The similar dimensionless parameters for Newtonian and non-Newtonian fluids should be achieved by adjusting the inlet velocity and pulse frequency at the inlet of selected artery.

\section{Results}

An experimental setup was developed for visualization of particles flow in the selected artery of systemic circulation. The scheme of the setup is presented in Fig. 4. This setup could be used for a fast determination of main flow features in the selected artery: vortices, flow separation region, backflow and so on. Particles are used to visualize the flow field. The setup consists of pump (1), reservoir tank (2), overflow tank (3), flow meter (4), pressure transducer (5), container with particles (6), model of artery (7) and pressure transducer (8). The flow visualization is conducted under the steady flow conditions. The overflow tank ensures the constant inlet pressure at the model. Pressure transducers are used for control of inlet and outlet pressure. Flow meter used to control the inlet flow rate in the artery model. Two valves were added to the model to connect the main flow with the container with particles. Depending on the task of a study the particles could be injected into the main flow at arbitrary time.

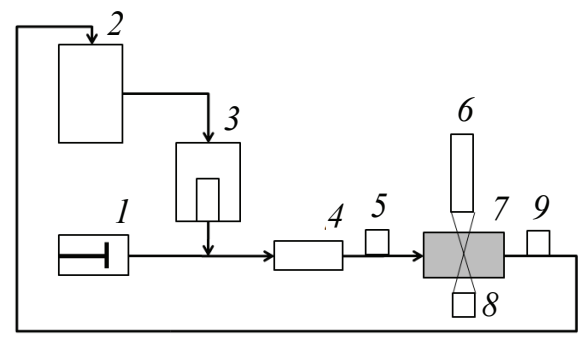

Fig. 6. Block diagram of experimental setup for velocity measurements in the selected artery
The example of flow visualization with particles is shown in Fig. 5.

For a detailed evaluation of velocity field in the model of selected artery the following experimental setup could be used. The scheme of the setup is presented in Fig. 6. Experimental setup includes a high precision measuring device such as 3D LDA or PIV system. In the example the LDA system was used, consisting of laser (6) and 
photomultiplier (8). The measurements could be done under pulsatile or steady flow conditions. The overflow tank (3) ensures the steady inlet pressure for the model (7). Programmable piston pump (1) generates the realistic inlet flow rate, which is controlled by the flow-meter (4). The inlet and outlet pressures are measured by the pressure transducers (5) and (9). The piston pump is activated when the pulsatile flow conditions are required.

Conclusion. In this study we present a detailed description of two experimental setups for evaluation of blood flow in arteries of cardiovascular system. Experimental setup for visualization of the flow could be used as a preliminary tool for the fast detection of main flow features. The detected regions of interest then could be studied in detail by the experimental setup with a high-precision measuring device. The measured flow field should be analyzed to detect the regions prone to vascular diseases and estimate the risk of a disease. The described experimental setups could be used to assist a physician in clinical decision-making process.

The work was supported by DAAD (German Academic Exchange Service) for the "Mikhail Lomonosov" program and within the framework of the state project No. 18.706.2016 / DAAD.

\section{References}

1. Hastings N., Simmers M., McDonald O., Wamhoff B., Blackman B. Atherosclerosis-prone hemodynamics differentially regulates endothelial and smooth muscle cell phenotypes and promotes pro-inflammatory priming, The American Journal of Physiology - Cell Physiology, 2007, vol. 293, no. 6, pp. 1824-1833.

2. Jeong W., Rhee K. Hemodynamics of cerebral aneurysms: computational analyses of aneurysm progress and treatment, Computational and Mathematical Methods in Medicine, 2012, vol. 2012, pp. 1-11.

3. Azrani A., Suh G., Dalman R., Shadden S. A longitudinal comparison of hemodynamics and intraluminal thrombus deposition in abdominal aortic aneurysms, The American Journal of Physiology-Heart and Circulatory Physiology, 2014, vol. 307, no. 12, pp. 1786-1795.

4. Marsden A., Esmaily-Moghadam M. Multiscale modeling of cardiovascular flows for clinical decision support, Applied Mechanics Reviews, 2015, vol. 67, no. 3, pp. 1-11.

5. Morris P., Narracott A., von Tengg-Kobligk H., Silva D., Hsiao S., Lungu A., Evans P., Bressloff N., Lawford P., Hose D., Gunn J. Computational fluid dynamics modeling in cardiovascular medicine, Heart, 2016, vol. 102, no. 1, pp. 18-28.

6. Frolov S.V., Sindeev S.V., Lischouk V.A., Gazizova D.Sh., Liepsch D., Balasso A. Development of multiscale hemodynamics model for research of basilar artery circulation, Problems of Contemporary Science and Practice. Vernadsky University, 2013, vol. 48, no. 4, pp. 46-53.

7. Frolov S.V., Sindeev S.V., Liepsch D., Balasso A. Mathematical modelling of blood flow in basilar artery bifurcation region, Transactions of the Tambov State Technical University, 2014, vol. 20, no. 1, pp. 50-58.

8. Mijovic B., Liepsch D. Experimental flow studies in an elastic Y-model, Technology and Health Care, 2003, vol. 11, no. 2, pp. 115-141.

\section{Список литературы}

1. Hastings, N. Atherosclerosis-prone Hemodynamics Differentially Regulates Endothelial and Smooth Muscle Cell Phenotypes and Promotes Pro-Inflammatory Priming / N. Hastings, M. Simmers, O. McDonald [et al.] // The American Journal of Physiology - Cell Physiology. - 2007. - No. 293(6). - P. 1824 - 1833. 
2. Jeong, W. Hemodynamics of Cerebral Aneurysms: Computational Analyses of Aneurysm Progress and Treatment / W. Jeong, K. Rhee // Computational and Mathematical Methods in Medicine. - 2012. - No. 2012. - P. 1 - 11.

3. A Longitudinal Comparison of Hemodynamics and Intraluminal Thrombus Deposition in Abdominal Aortic Aneurysms / A. Azrani [et al.] // The American Journal of Physiology - Heart and Circulatory Physiology. - 2014. - No. 307(12). - P. 1786 - 1795.

4. Marsden, A. Multiscale Modeling of Cardiovascular Flows for Clinical Decision Support / A. Marsden, M. Esmaily-Moghadam // Applied Mechanics Reviews. 2015. - No. 67(3). - P. 1 - 11.

5. Computational Fluid Dynamics Modeling in Cardiovascular Medicine / P. Morris [et al.] // Heart. - 2016. - No. 102(1). - P. 18 - 28.

6. Development of Multiscale Hemodynamics Model for Research of Basilar Artery Circulation / S. V. Frolov [et al.] // Вопр. соврем. науки и практики. Университет им. В. И. Вернадского. - 2013. - № 48(4). - Р. 46 - 53.

7. Mathematical Modelling of Blood Flow in Basilar Artery Bifurcation Region / S. V. Frolov [et al.] // Вестн. Тамб. гос. техн. ун-та. - 2014. - № 20(1). - P. 50 - 58.

8. Mijovic, B. Experimental Flow Studies in an Elastic Y-model / B. Mijovic, D. Liepsch // Technology and Health Care. - 2003. - No. 11(2). - P. 115 - 141.

\section{Экспериментальные установки для исследования кровотока в артериях сердечно-сосудистой системы}

\section{С. В. Синдеев, С. В. Фролов, Д. Липш}

ФГБОУ ВО «Тамбовский государственный технический университет», г. Тамбов, Россия;

Мюнхенский университет прикладных наук, г. Мюнхен, Германия

Ключевые слова: биомеханика; большой круг кровообращения; гемодинамика.

Аннотация: Гемодинамика играет важную роль в генезе таких сосудистых заболеваний, как атеросклероз, тромбоз и аневризма. Понимание условий кровотока в областях, имеющих потенциал к развитию таких заболеваний помогает врачу в процессе принятия клинических решений. Представлено детальное описание двух экспериментальных установок для оценки кровотока в артериях сердечнососудистой системы. Экспериментальная жидкость может быть ньютоновской или неньютоновской. Одинаковые безразмерные параметры - числа Рейнольдса и Струхаля, должны быть использованы для сравнения ньютоновской и неньютоновской жидкостей в моделях. Экспериментальную установку для визуализации потока возможно использовать как предварительное средство для быстрого обнаружения основных особенностей кровотока. Интересующие области могут быть детально изучены с использованием экспериментальной установки, включающей высокоточное устройство измерения. Измеренное поле скоростей потока необходимо проанализировать для обнаружения областей, где возможно сосудистое заболевание и оценки риска его возникновения. Представленные экспериментальные установки могут быть использованы для помощи врачу в процессе принятия клинических решений. 